\title{
Premodern Confederacies: Balancing Strategic Collective Action and Local Autonomy
}

\author{
Jennifer Birch * \\ Department of Anthropology, University of Georgia, Athens, GA, United States
}

A confederacy is generally understood to be a formal, institutionalized alliance of peoples who act in mutual support to achieve common ends. While the emergence and maintenance of early and pre-modern states have received tremendous scholarly attention in the social sciences, the same cannot be said for confederations. This paper examines common features of premodern confederacies as an initial effort towards developing a body of theory aimed at exploring and explaining confederacies, leagues, and other modes of collective and regional governance. The central thesis posed is that confederation was an ongoing political process that provided a means for a diverse range of political formations to achieve collective strategic goals at a distance without sacrificing autonomy. Selected case studies ranging from Pre-Columbian North America

Edited by:

Gary M. Feinman, Field Museum of Natural History,

United States

Reviewed by:

William Engelbrecht,

Buffalo State College, United States

Peter Peregrine,

Lawrence University, United States

John Millhauser,

North Carolina State University,

United States

${ }^{*}$ Correspondence:

Jennifer Birch

jabirch@uga.edu

Specialty section: This article was submitted to

Comparative Governance,

a section of the journal

Frontiers in Political Science

Received: 01 November 2021

Accepted: 13 January 2022

Published: 09 February 2022

Citation:

Birch J (2022) Premodern Confederacies: Balancing Strategic Collective Action and Local Autonomy.

Front. Polit. Sci. 4:807239.

doi: 10.3389/fpos.2022.807239 to Medieval Europe are explored to evaluate this position. The case studies show that confederacies were capable of integrating a diverse range of political formations, from tribes to kingdoms. The question of whether or not confederacies constitute 'good government' is considered and since the objective of a confederacy is generally not to govern, the answer depends on the political organization of its constituent parts.

Keywords: confederacies, theory-building, cross-cultural comparison, military, economy

\section{INTRODUCTION}

A confederacy is generally understood to be a formal alliance of peoples who act in mutual support to achieve common ends. In the modern era, confederations have come to be associated with unions of sovereign states that stress the autonomy of each constituent part (e.g., the German Confederation, ca. 1815-1848 CE or Confederate States of America, ca. 1861-1865 CE). However, confederacies as formal strategies for achieving collective objectives have a deep past. In multiple world regions over the last $\sim 5,000$ years, autonomous political units formed institutions to advance their mutual ends. While variable in their character and organization, all exhibit a significant degree of organizational complexity and diversity. Yet, because they do not fall neatly into step-wise neoevolutionary stages of social complexity-instead operating on a multilinear plane parallel to more "complex" polities such as premodern states-confederacies remain under-theorized with respect to their evolution and organization.

Here, I examine common features of premodern confederacies as an initial effort towards developing a body of theory aimed at exploring and explaining confederacies, leagues, and other modes of regional collective action. Formalized institutions and conventions allowed members to secure collective benefits at a distance most often including collective defense and economic interdependence. Selected case studies of premodern confederacies are explored. This is not intended to be an exhaustive review. The purpose is to examine specific variables and processes 
involved in the emergence, purpose, and maintenance of confederacies. General properties to be explored include the historical conditions of their emergence; modes of governance; strategic aims or goals; territory and demography; economy; and the conditions under which such they dissolved or were otherwise transformed into something else. Information comes from both archaeological and historical sources and not all data are available for every case. Taken as a whole, a generalized theory of why confederacies emerge, how they are sustained, and why they might eventually unravel or be transformed starts to take form.

I argue that rather than being viewed in social evolutionary terms, confederation should be understood as a processual organizational strategy that was effectively employed by a wide variety of socio-spatial configurations-from villages to citystates and pastoralists to intensive agriculturalists. Although the confederacies that most influenced political and anthropological thought were composed of "tribal" nations (i.e., Engels, 1884; Morgan, 1851; Morgan, 1877), premodern confederacies in fact included all manner of socio-political configurations, from loose coalitions of autonomous villages to kingdoms. It will be shown that premodern confederacies comprised purposeful compacts between regionally dispersed groups that allowed populations to achieve collective benefits without sacrificing local autonomy. Ultimately, the nature and durability of premodern confederacies in relates directly to the historical conditions that fostered their emergence, maintenance, and dissolution or transformation.

\section{What is a Confederacy?}

Defining "confederacy" is not so much about what a confederacy is but the process and objectives of confederation.

Early identification of confederations in political scholarship can be traced back to Hermann (1836) and Morgan (1851, 1877) who identified confederacies of kin-based clans or tribes in ancient Greece and northeastern North America, respectively. In each case, it is noted that the confederation of political groups was purposeful, with the ability to engage in foreign policy and joint military action being foremost among those purposes (Hermann, 1836: 23; Morgan, 1877: 120). However, as expanded upon below, the purposeful and processual nature of confederation was aimed at securing collective action benefits and not coercive power.

Another definition of confederacy, from Tapper (1990: 68), considers it "a union of tribal groups for political purposes, sometimes on the basis of imputed common descent ... usually with central leadership ... but sometimes without-though some would term such an uncentralized alliance a coalition." Two things about Tapper's definition need qualifying in the context of the case studies presented in this paper. First, the groups that come together to form a confederacy need not necessarily be "tribal." Confederacies of chiefdoms, cities, and states can also be identified. The second portion of Tapper's definition does however apply. For our purposes, a confederacy must have a formal, institutional basis that distinguishes it from less formal alliances, compacts, or coalitions. Further, the institutional basis of a confederacy will provide an overarching, formal framework for organizing collective action without supplanting the institutional and political autonomy of its component parts. In order to achieve purposeful action, a political apparatus must be created and maintained in order to achieve the collective aims of the confederacy. This apparatus may also change in form, size, or nature over time. These structures typically consisted of councils or assemblies composed of representatives of pre-existing social and political units. In many ways, the process of forming and maintaining those institutional structures constituted what a confederacy was-a process of ongoing confederation-as opposed to a societal type.

The most important aspect of the nature of confederacy governance in opposition to more centralized polities is the balance between the preservation of local autonomy and the pursuit of collective action. In other words, those groups seeking to form confederacies want no part of Hobbes' social contract and the exchange of free will for centralized authority. In terms of governance, it is the leaders or representatives of the constituent groups that actually do the business of governing, whereas the role of the confederacy and its leadership is to organize and act to fulfil the objectives of the confederacy. Members of confederacies included groups of varying sizes, with distinct ethnicities, identities, fiscal and governing structures, and interests. This meant that the constituent leaders, towns or provinces, and citizens were potentially in conflict. Maintaining the balance between autonomy and cooperation took a great deal of work, and for that reason confederation should be understood on processual terms. The initial purpose and form of a confederacy at its founding may have changed as that purpose and its constitution evolved. When the historical (internal or external) conditions that fostered the strategic aims of a confederacy change, it may dissolve into its constituent parts, i.e. clans, tribes, towns, or be otherwise transformed into a more centralized polity, i.e., a state or kingdom through the same processual means.

\section{Why (or when) Might a Confederacy be "Good Government?"}

Marx and Engels were strongly influenced by Morgan's ethnological description of the organization and underlaying political philosophy of the Haudenosaunee confederacy as an evolutionary precursor of class-based society in the Marxist critique (Hunt, 2010). Engels' The Origin of the Family, Private Property and the State (1884) comprises a review of alternative forms of social organization based on gens or extended kin-based groups. There, he aligns Morgan's (1877) ethnographic descriptions of the Haudenosaunee and other segmentary societies with Marx's historical materialism. As stated by Hunt (2010: 9): "In early 1882, as Marx was ... in the Isle of Wight, Engels wrote to him ... in order finally to get clear about the parallel between the Germans of Tacitus and the American Redskins [sic]." While Engels' (1884) focus is the changing role of the family and modes of production in the development of inequality, here that same comparison is made in service of understanding the political institution of the confederacy as the basis for strategic collective action. 
Blanton and others' framing of "good government" is based on central tenets of collective action theory. Chief among these is the notion that cooperation based on mutual moral obligation arises primarily out of the management of jointly shared resources (Levi, 1988; Ostrom, 1990). Further, they postulate that "good government" based on collective action includes the following characteristics following (Blanton et al., 2020; Blanton et al., 2021): A mechanism for allowing the voices of the citizenry to be heard in political decision-making; checks on limits for the accumulation of power; private wealth does not play an uninhibited role in political agency; leaders have little control over fiscal economy; and provision of benefits to citizens.

The aforementioned principles have primarily been used to evaluate good government in states. In using the same to evaluate whether or not confederacies constitute good government I add two guiding hypotheses: 1) That confederacies strike an institutional balance between securing collective interests at a distance and maintaining local autonomy, and; 2) that confederacies emerge to achieve strategic, purposeful aims. The purpose of premodern confederacies was not governance of the persons whose leaders or representatives formed the confederacy but related to policy, actions, and affairs of the confederacy as they related to other, often external, conditions. Predominant among these are objectives that secure military and economic benefits for all confederated parties.

\section{Characteristics}

In addition to the premise that confederacies permit local autonomy while allowing members to achieve strategic objectives, we should expect premodern confederacies to be defined by the following characteristics:

History and formation: Historical conditions as opposed to generalizable models of societal development foster the development of confederacies. These may include external pressures such as conflict or encroachment by other more powerful or militaristic entities. In many cases, the historical conditions of confederacy formation emerged from the coalescence of ethnically and linguistically diverse groups. In better understanding the historical and cultural contexts of confederacy formation we can better understand the conditions that foster confederacy-building as an alternative to centralization.

Territory and Demography: Maintaining collective action at a distance-the carrying out of joint objectives among dispersed, diverse, and autonomous populations was one of the essential functions of premodern confederacies. Unlike the familiar coupling of the state and urbanism, confederacies included settlement strategies comprising villages, towns, cities and nations, as well as both agricultural and pastoral lifeways. Territories occupied by members of a confederacy may or may or may not be contiguous but they are often expansive. Populations of confederacies as a whole vary between tens to hundreds of thousands.

Institutional basis of leadership: Confederation promotes effective collective action at a distance. Compacts among constituent groups were more formal than simple agreements or alliances and were maintained by institutions, constitutions, and rules based on collective action and perceptions of collective benefit. Although the organizational basis of confederacy governance may have included hierarchical or heterarchical ranking, structural principles provided checks on the accumulation of power or authority by any one person, faction, or group. As a result, coercion is minimal. Leadership positions may be achieved or inherited, although in many cases positions of authority were limited to facilitating consensus. Because the institutional structure and leadership of a confederacy will preserve the autonomy of the participating groups, leaders do not have the ability to interfere in the affairs of groups beyond their own.

Economy and financing: In this case, collective action is not based on the management of collective resources, but rather achieving one or more mutually beneficial objectives. Financing of the confederacy should be tied directly to those objectives and not governing per se. We should expect premodern confederacies to be characterized by economic independence and interdependence. One function of confederation was to reduce transaction costs and promote exchange among member groups. Collective policies regarding external trade may enhance longdistance trade relations. The financing of collective activities or activities with collective benefits are organized in ways that did not impinge on the autonomy or well-being of local groups.

Dissolution and Transformation: In keeping with their purposeful nature, confederacies are unlikely to persist beyond the historical conditions that necessitated their formation. While some confederacies were dissolved as the result of military losses or colonial encroachment, others were transformed into new organizational forms, including states and republics.

The aforementioned hypotheses and characteristics will be evaluated in the context of the following case studies. Of course, not every case will possess each of these attributes, contingent upon on the amount of information available or the unique historical circumstances of each group. Each is intended as a general sketch and thus certain complexities and controversies may be overlooked, however taken as a whole the selected cases support the primary arguments put forth herein.

\section{North America}

\section{Northern Iroquoian Confederacies}

In the 17th century, at least two Northern Iroquoian populations were organized into confederacies: the Haudenosaunee (Iroquois) and Wendat (Huron). Each formed in the later 1400s-1500s CE and were encountered by early European explorers, missionaries, and colonizers during the early 1600s-1700s CE. These were sizable groups, each with an estimated population of some 20,000-30,000 (Jones, 2008; Warrick, 2008). Although the basic social institutions in Huron-Wendat and Haudenosaunee societies were identical below the confederacy level, territorial considerations and the process by which each formed led to differences in their internal structure and functions (Birch, 2020).

Nations of the Haudenosaunee developed more or less in situ and their descendants remain in their traditional homelands in central and northern New York and adjacent regions to the present day. The Haudenosaunee confederacy emerged in the context of endemic warfare among its members. The founding 
mythology for the confederacy describes the circumstances of the League's founding whereby the culture hero Deganawidah (the Peacemaker) travelled to each Nation bringing the message of peace and the mechanisms for ensuring it (Wonderley and Sempowski, 2019). Non-aggression pacts included protocols for ceremony and reparations if violence broke out amongst members.

The founders of the "Great Peace" designated 50 chiefly titles that were distributed among the five nations of the confederacy such that each clan in each nation had one or more representatives on the confederacy council (Fenton, 1998). Because clan affiliation was shared across multiple member nations, authority was dispersed and this served to undergird the confederacy with dense webs of mutual obligation. While confederation quelled tensions amongst members, warfare remained an integral part of Haudenosaunee culture as a means of satisfying personal needs (status, prestige, male identity) and public duty (revenge, adoption of captives, foreign policy) (Brandão, 1997). The formalization of the Haudenosaunee confederacy did not involve the relocation of member nations, who continued to occupy villages in their home territories. This was not the case for their confederated neighbors to the north.

While the Wendat confederacy may have initially emerged as a close relationship or alliance between two founding nations (Trigger, 1976), its growth appears to have been catalyzed by Haudenosaunee aggression (Birch et al., 2021). Ultimately, the Wendat confederacy of 1615-1651 CE comprised four nations concentrated in the uplands between Lake Huron and Lake Simcoe, in Ontario, Canada. Many of these peoples had formerly inhabited territories to the south and east but were driven north by Haudenosaunee raiding parties. While in some cases entire nations were adopted into the confederacy, smaller social units such as families were also incorporated into its constituent villages and nations (Tooker, 1964:10-11).

There is less known about the precise internal functioning of the Wendat confederacy compared to the Haudenosaunee (Trigger, 1976:58-59), but its organizational structure seems to reflect its integrative and incorporative nature. The Wendat confederacy council was composed of most of the civil headmen who sat on the councils of each nation and represented the clan segments present in each. Day-to-day governance took place at the village level. While the vast majority of confederacy-wide activities concerned organizing for collective offensive and defensive action against the Haudenosaunee, ties were also maintained thorough participation in elaborate mortuary ceremonialism surrounding ossuary burial and the associated "Feast of the Dead" (Williamson and Steiss, 2003).

In both cases, the confederacy structure acted to reduce transaction costs between member Nations during the early years of European colonization and later fur trade. However, both archaeological data (distributions of Europeanmanufactured goods) and oral history indicate that economic relationships differed from village to village suggesting that trade and exchange was a community-to-community affair rather than being managed at the confederacy level (Brandão, 1997:106; Pavlish et al., 2018; Birch et al., 2021).
Ultimately, members of the Wendat confederacy were dispersed by Haudenosaunee attacks in 1650-1651, with the political core of the Huron-Wendat Nation re-establishing itself in Wendake, Quebec as the Huron-Wendat Nation. The League of the Haudenosaunee remained intact until January 1777, when the Five Nations were unable to reach consensus on whether to maintain diplomatic neutrality or side with the English in the American Revolutionary War. As a result, they decided to metaphorically "cover the Council fire," effecting a temporary suspension of the confederacy that permitted individual nations to act according to their own will (Parmenter, 2018:5). The contemporary Haudenosaunee confederacy, as reformed in the colonial era, remains an important political and social identifier for Iroquoian peoples.

\section{Muscogee Confederacy}

There were multiple Indigenous groups organized into confederacies in the early colonial American South. The Southeastern confederacies are thought to have formed following the fragmentation of the Mississippian chiefdoms of the ca. 1,000-1550 CE period (Ethridge and Hudson, 2002), however elements of collective governance, including councils and council houses, also existed in those earlier, more centralized polities (Thompson et al., 2022).

The most expansive of the Southeastern confederacies was the Muscogee (formerly called Creek) confederacy, which formed in the 1500s (Swanton, 1922) or 1700s CE (Knight, 1994) and persisted until the removal-cum-genocide of Native Americans in the 1820s and 1830s. The territory occupied by members of the confederacy included portions of the alluvial floodplains of several major river valleys in Georgia and eastern Alabama. Two distinct population clusters focused on groups of key towns distinguish the Upper and Lower Muscogee. Population estimates from the 18th century range from 10,000 to more than 24,000 in approximately 60 towns (Cobb, 2019:108; Muller, 1997: 174-175).

The Muscogee confederacy has been described as a "territorial assemblage of small groups ... with diverse cultural and linguistic backgrounds" (Knight, 1994:373). Some towns had been established in the region for hundreds of years and others were relative newcomers, having been displaced by the impacts of colonial encroachment, slave raiding, epidemic diseases, as well as the persistent population movements characteristic of Indigenous eastern North American societies. Demographic collapse, resettlement, and political volatility ca. 1,550-1650 CE is clear in both the archaeological and ethnohistoric records and created the backdrop against which Indigenous confederacies coalesced (Ethridge and Hudson, 2002; Cobb, 2019).

The Muscogee system of governance was based in part on shared values and pre-existing institutional forms (Chaudhuri and Chaudhuri, 2001:68-69). However, in the 18th century the primary purpose of the Muscogee confederacy was to provide a framework that permitted tribal towns (talwas) to organize for common action against external aggression and territorial encroachment. The formalization of the confederacy occurred directly as a result of European pressure. It most likely stabilized 
during the Yamasee war of 1715-16 (Knight 1994:386) and became the dominant Native polity in the region into the early 1800s, becoming a major player in early colonial America (Cobb, 2019:108; Weir, 2016:13). It accomplished this objective without influencing the social organization and selfgovernance of the towns and tribes that were its constituent parts (Knight, 1994:374).

While members of the confederacy are often referred to by their ethnic (tribal) referents (e.g., Muscogee, Seminole, Hitchiti, Yuchi, Natchez, Alabama), governance took place at the level of the tribal towns, each of which possessed a square ground and the public and ceremonial facilities and offices associated with each.

The primary institutional framework for the confederacy was a National Council. A National Chief presided over the council. Chiefs from the member towns (talwa micco) attended these meetings. Chiefly offices were not hereditary and fitness was determined by community acceptance. There was no central or regular meeting place and meetings of the National Council were called in towns throughout Muscogee territory (Chaudhuri and Chaudhuri, 2001:71). While decisions were reached by consensus, all towns within the confederacy were not equal. Larger, more conservative towns served as "foundation towns" and smaller towns either formed by fission or were affiliated as the result of inmigration and adoption (Knight, 1994:375). Below the confederacy level were towns were organized into provinces headed by a "Great Chief" (micco thakko). Towns were also organized into moieties within each province. Miccos were chiefs with specified functions (Chaudhuri and Chaudhuri, 2001:8). While most Miccos were traditionally men, at least one female Micco is noted in the ethnohistoric record (Hudson 1997: 174-175). In addition to civil roles and in keeping with the importance of coordination for effective military action, the Muscogee had dedicated military offices. These included gradations of soldiers and sergeants (tustenagee) as well as war chiefs (yaholas). The mobilization of military leadership was subject to the general decision-making of the Muscogee Confederacy (Chaudhuri and Chaudhuri, 2001:77-78). Clan mothers also formed councils that dealt with issues such as the treatment of prisoners, arbitration of disputes, and violations of social policy (Chaudhuri and Chaudhuri, 2001:8). Specialized runners and teams of runners relayed important information from village to village and province to province (Chaudhuri and Chaudhuri, 2001:70).

The Muscogee subsistence economy was primarily agricultural in nature, supplemented by hunting, fishing, and foraging. Extensive exchange networks carried prestige goods such as marine shell and copper, as well as salt and other commodities. Plazas may have served as foci for both politically-charged and market exchange (Kowalewski and Thompson, 2020). In the later 1600s and 1700s, they also traded captives, deerskins, and furs with Europeans in exchange for European-manufactured goods (Lapham, 2005).

In 1813-1814, civil war (a.k.a., the Red Stick war) broke out among the Muscogee. It began as a conflict within the confederacy and expanded to include other Native enemies (the Choctaw and Cherokee), American militias, and interference from colonial powers (British and Spanish agents)
(Weir, 2016). Military conflicts, land cessations, and genocidal policies of the United States government ultimately resulted in the forced removal of the Muscogee from their historic homelands in Georgia and Alabama to Oklahoma. While 4,000 people died on this journey and 3,000 more on arrival (Butler, 2021) the contemporary Muscogee Nation is a selfgoverning nation of more than 81,000 . They have retained the National Council as their central governing institution, although many aspects of Western-style centralized government have necessarily been incorporated.

\section{Near East}

Confederacies have been recognized as a political strategy deployed frequently in Near Eastern archaeology and history. Some scholars have argued that the tribal confederacy as a social formation had its origins in the early Bronze Age village and pastoral tribal communities of the Levant with the aim of controlling trade between Egypt and areas north (Finkelstein et al., 2000; van der Steen, 2005:11). However, these arguments are loosely defined and evidence is lacking for the institutional basis of confederation as defined herein.

Ancient Egyptian and Assyrian sources documented the existence of tribal confederacies on the borders of their empire. The most famous Near Eastern confederacy may be the Biblical twelve tribes of Israel. Israel's development from a tribal society led by heroic patriarchal figures to a state includes a stage in which it comprised a confederacy or league of tribes (Gottwald, 1979; Martin, 1989). According to Biblical texts, the Hebrews begin to consolidate their tribal confederacy in the uplands of the later Judaea and Samaria. Their common purpose is understood to have been defense against the militaristic Canaanite city states and the Philistaeans in the fertile coastal plains, both of which possessed superior weaponry (Zank, 2008). The Israelites' god is said to have endorsed tribal leaders, war lords, and judges, but not a single permanent leader or king. Smith (2003) details the political and moral tensions between the decentralized, tribal federation of the Israelites and the emergent intuition of kingship under David in the Hebrew scriptures. Israel's perception of itself as a confederation persists into the present day despite its transformation into a Nation State.

Hittite sources note an entity or territory in western Anatolia known as "Arzawa” (MacSweeney, 2010). Coalitions of Arzawans are recorded at several points throughout Hittite history from the Old Kingdom (ca. 1,650-1500 BCE) onwards, but in the 1200s a local ruler named Uhhaziti managed to unite the majority of the Arzawan groups into a pan-Arzawan confederacy that the Hittites considered a serious threat (Mac Sweeney, 2010:8). The result was aggressive military action that annexed the Arzawans and broke the confederacy up into three separate kingdoms.

In more recent Near Eastern history, in the 18th century, the Shahsevan confederacy emerged in opposition to the Ottoman empire (Tapper, 1997). Originally, the term shahisevani referred to loyalty and military service owed to the Safavid (Persian) Shahs and the Shia faith who dominated the area of present-day Iran from the 1500s-mid 1700s. By the 18th century, the Shia faith 
became well-entrenched, the overarching authority of the Safavid had dissipated, and overcrowding of pastures and political fragmentation led to an overall sense of insecurity and disorder. In some parts of the region, chiefdom-like political structures emerged, organized around a chief or khan who could provide security, order, and some stability (Tapper, 1997: 129-136). These chiefs, together with other tribes and fragments thereof would come together in the 1760s as the Shahsevan confederacy.

The Shahsevan confederacy included both "commoner" (less powerful) and "noble" (more powerful) tribes with an appointed leader (khan). The Kahn had broad military and judicial powers, subject to consultation with a council of clergy (mullahs) and elders. There was an expectation that taxes would be collected, ostensibly to fund the Khan's entourage of courtiers, servants, and guards, as well as public officials, but local chiefs were in effect autonomous. The economy and society of ordinary nomads were little changed by the formation or dissolution of the confederacy (Tapper, 1997: 142-143). Trade and exchange do not seem to have been a priority of the confederacy, which functioned primarily to present a united front against the Ottoman Empire and provide basic regional governance. Ultimately, the confederacy broke apart amidst factionalism and power struggles among leading chiefs and tribes.

Tapper (1990) highlights later, more modern cases in where tribal confederacies form in opposition to external pressures from state governments or where centralized tribal unions form as part of a process of secondary state formation. In the latter case, they do not fit our definition of "confederacy" here, but rather more resemble secondary state formation among ethnically "tribal" peoples outside the margins of dominant Islamic urban society.

\section{Late Roman and Medieval Europe Germanic Tribal Confederacies}

Scholarship of the later Roman Migration period includes descriptions of the "barbarians" who would ultimately bring about the decline of the western Roman Empire. Most of these were written by Roman chroniclers who did not have knowledge about the internal political organization of the tribes and confederations among them. For example: "Caesar describes tribes and confederacies that had little in the way of constitutions. The barbarians relied on conventions that facilitated infrequent political action of a limited range" (Young, 2015:359). Agreements and alliances among Germanic tribes may not have always met the definition of a formal confederation. However, in some cases they did form institutional arrangements that fit our definition of confederacy. Heather (2010:54) notes that while Germanic tribes of the first century were certainly capable of assembling supertribal confederations, the evidence suggests that they were primarily religious in organization, i.e., the "cult leagues" described by Tacitus, or short-lived from a unified, political standpoint. Organization for military purposes seems to have altered those dynamics and, in many cases, political units were created "on the march" with recruitment from a wide range of ethnic and linguistic populations (Heather, 2010:35).

In $357 \mathrm{CE}$, a "huge" army of Germani assembled near the modern city of Strasbourg was described as being led by various "kings" of the Alamanni (Heather, 2010:52). Another fourthcentury confederation, the Tervingi, located in the foothills of the Carpathians and dominated by the Goths functioned in a similar manner to the Alamanni, though with a slightly different institutional structure based on leading "judges" (Heather, 2010:57). These confederations were not small. Estimates suggest the Alamanni and Tervingi could field some 10,000-20,000 warriors, suggesting total group sizes of 50,000-100,000, although Heather (2010:74) suggests what accounts there are underestimate the size of the total confederated population. Both cases provide compelling evidence of the ability of Late Iron Age and early Medieval Europeans to develop and maintain collective institutional means of promoting common strategic objectives at a distance without sacrificing local autonomy.

Alamanni kingship was hereditary and kings, princes, and other elites (optimates) presided over a series of sub-regions (cantons or gau). Repeated Roman attempts to put down the confederacy by eliminating these kings in combat was apparently not enough, as new leaders would emerge and the basis of collective action as a whole could not be undermined by such defeats (Heather, 2010:55-57). Heather (2010):56 writes that "Like many late antique and early medieval confederative entities, the Alamanni had, I suspect, an established repertoire of political and diplomatic conventions which defined and bound together their various kings in positions of overking and underking, the latter owing allegiance and some duties to the former, while still retaining direct day-to-day control of their own cantons."

Although participation in these Germanic confederacies may have initially been based on the principles of "good government" from the perspective of the general population, over time that social contract appears to have eroded. By the fourth century, it appears that Germanic leaders were able to extract labor, agricultural production, and coerced military service from the populace. This seems to have evolved in part, as kings and princes sought Roman goods and the creation of obligatory relations between their principalities and Roman authorities through the provision of taxes and military support (Heather, 2010:7).

For example, when they appear on the Danube Frontier in the second century, the Vandals were likely a militarized aggregation of peoples described as a confederacy (Wickham, 2016:25). By the fourth century this loose aggregation had become more formalized, and Vandal kings were certainly in place during the crossing of the Rhine in $405 / 6$ CE. But as was the case for the Alamanni, the death of specific kings in various military engagements did not seem to alter the trajectory of the Vandals as a whole. While the Vandals as a people on the move may have been based on a confederation of kingships, during the time that they entered the western Roman Empire, marched across Iberia and crossed into north Africa this was no longer the case. Upon establishing themselves in Algeria, ca. $429 \mathrm{CE}$ and succeeded in 
cutting Carthage off from the rest of the Roman Empire one Vandal king, Gieseric, managed to consolidate power into a more centralized kingdom (Merrills and Miles, 2010:57-58, 70).

These developments in bureaucratic infrastructure and the emergence of entrenched social stratification ultimately set the stage for the emergence of more familiar forms of feudal Medieval governance in the late first millennium $\mathrm{AD}$.

\section{Early Medieval Ireland}

Gibson $(2011,2012)$ has made a compelling case for the existence of chiefdom confederacies in Early Medieval Ireland and compares them to certain other of the cases described herein. He defines these political confederations as chiefdoms that adopted a common identity and endonym and which were unified through common agreement (Gibson, 1995: 23; 2012: 31).

Although chiefdom confederacies appear as early as the fifth century in central Ireland (Gibson, 2012:30), the best documented is the Dál Cais confederacy of Thomond located in the Early Medieval Irish province of Munster (consistent with the modern County Clare) (Gibson, 2012). The Thomond confederacy first appears in the documentary record of the early 10th century and persisted until the 12th century CE. The constituent territories of Early Medieval Irish chiefdom confederacies were typically located near one another but were not necessarily territorially contiguous (not unlike the Haudenosaunee). While specific population estimates for this region are difficult to extrapolate, based on the total estimated population of Medieval Ireland as a whole (Hannah and McLaughlin, 2019) we can assume we are dealing with a population on the order of thousands to tens of thousands.

Textual sources describe the formation of a confederacy by chiefs of the west Munster region with the rationale of mutual defense. These chiefs were skilled in building and maintaining alliances and Gibson (2011:219) suggests that confederacies were created to facilitate predatory military expansion on the part of the confederacies' leaders. In either case, we see the same purposeful military compact as is the case in other examples. However, certain of these confederacies were also unified by coercive agreements, straining the conditions of local autonomy outlined herein. For these chiefly confederacies to hold up to the principles of good government, those that are overly coercive may or may not fit the bill.

The leading families of these chiefdoms were members of ranked clans. Documentary records indicate that the purported kin relations between the founding ancestors of each of the constituent chiefdoms remained intact for hundreds of years (Gibson, 2011:217-219). While succession to leadership was restricted to a given aristocratic lineage, new leaders were validated in an assembly and in at least one case, two apical chiefdoms had an agreement to alternate the paramountcy alternately during times of succession (Gibson, 2011:225).

While the subsistence economy of Early Medieval Ireland was agrarian, the political economy of Medieval Irish chiefdom confederacies was dominated by livestock management, principally cattle (Gibson, 2012:137).
The end of the confederacy of Thomond came about in the early 12th century CE when Muirchertaich Uí Brian created the first state in Munster (Gibson, 2011:218).

\section{Old Swiss Confederation}

The Old Swiss confederation originated in western Habsburg lands around Lake Luzern in 1291 CE. The formation of the confederacy was finalized by the joining of all thirteen cantons (member units) by $1513 \mathrm{CE}$ and at this time its population was estimated to number in the hundreds of thousands (Wickham, 2016:227). It is the precursor of the modern state of Switzerland though the original footprint was somewhat less than the modern Swiss territory.

The Old Swiss confederation is claimed to have begun with a peace agreement between the three cantons of Uri, Schwyz, and Unterwalden. The Federal Charter states the purpose of the confederation as being to advance common interests such as free trade and mutual defense. The original "Eight Old Cantons" came together before 1,353 and possessed rights and privileges in external affairs that were not extended to the five that joined after (Würgler, 2008:29-30). Both the confederacy and it is member polities maintained alliances and treaties with other external powers, notably the French (Würgler, 2008:32).

To promote effective implementation of the confederacy's diplomatic, military, and economic objectives, they established an overarching institutional structure. This was loose at first, however, after $1500 \mathrm{CE}$ the Federal Diet (Tagsatzung) a legislative and executive council of delegates from the individual cantons was established. Each canton was equal in principle and each had one vote in council, regardless of the number of delegates or the population of the territory (Würgler, 2008:33). Cantons in turn held their own diets. The government did not rule over the confederated towns-each was politically and fiscally autonomous. Although the thirteen cantons together formed a contiguous territory, their geography, religious and political structures were diverse. In terms of governance, some were rural and democratic, some were urban, and others had patrician or guild-based constitutions (Würgler, 2008:33, see similarities with the Mayapan provinces, below).

According to Würgler (2008:38): "Internal stability was sustained by various economic structures. A complex division of labour kept the plains dependent on the milk and cattle produced in the mountains, while the mountain cantons depended on the grain that came from the plains and foreign markets."

In addition to establishing mutual security and economic benefit within their territories, most cantons were subject to the Habsburgs, and in $1386 \mathrm{CE}$, they jointly fought off an army sent to restore Austrian rule. This resulted in the defeat and death of the Habsburg duke Leopold III, giving the Swiss confederation a measure of confidence and legitimacy that allowed it to extend its range (Wickham, 2016:227). Some fighting did take place amongst cantons and their constituent parts, on account of the conflicting interests of nobles, towns, and peasants. However, a flexible military strategy allowed for the rapid deployment of infantry across the confederated territories. Part of their military success was owed to a highly capable 
peasant-based military. So successful were the Swiss in training their citizenry, that they were used as mercenary forces by other powers. Although the confederacy passed laws prohibiting citizens from entering foreign military service of their own accord and requiring foreign powers to petition the Diet and negotiate terms, in practice however both Swiss men and foreign rulers usually ignored the regulations (Dean, 2012). In these ways, the Swiss confederacy attempted more of the business of governing the citizenry than can be observed in other cases discussed herein. The Swiss are also one of the longest-lived confederations identified, persisting for more than 500 years and its ideals continuing to constitute certain aspects of the modern Swiss state, suggesting a certain degree of "good" governance evidenced by the retention of multiple territorial and ideological facets.

The confederation came to an end in 1798. However, it was not without internal conflict during this period and both internal and external mediation (organized by the French in many cases) prevented the confederation from breaking apart or otherwise dissolving (Würgler, 2008:36). However, its end came about not from internal discord per se but from the rise of Napoleon and the invasion of the French Revolutionary Army (Schelbert, 2014).

\section{Greece \\ Archaic Greece}

During the Greek Archaic period, ca. 1000 BCE-650 BCE, political systems described as ethnos dominated the central and western portions of modern-day Greece. These primarily consisted of loose associations of affiliated villages and territories. Others developed a more formal confederation, as was the case for the much-studied Boiotian League (e.g., Buck, 1979; Mackil, 2013; Gartland, 2016). A sense of ethnic unity seems to have pervaded these early political experiments and encouraged people to see them in a positive light (Mackil, 2014:276).

Boeotia lies to the north of the eastern part of the Gulf of Corinth in central Greece. The Boiotian League developed around 500-525 BCE in response to hostilities between Boiotians and the Thessalians to the north and threats from Athens from the south (Mackil, 2013:24).

The League was dominated by Thebes, but each participating town was represented in the governing assembly (halia) and each nominated dedicated military leaders (boeotarchs) (Buck, 1979: 124-125). The objectives of the League focused on "joint military action and the integration of local economies within the region" (Mackil, 2013:29).

The governments of Boiotian towns (poleis) and villages consisted of councils of magistrates who were the heads (or chiefs) of noble clans (gene). One magistrate, the Archon, was first among equals and bore symbols that reflected their religious and military functions. These roles circulated on an annual basis (Buck, 1979: 92-93). Encroachment of the central governing body was prevented by the local councils of individual cities, to which all important questions of policy had to be submitted for approval.

Boiotian towns were organized into districts for administrative purposes. Districts coordinated to meet military levies and were taxed in a "strikingly equitable" fashion on the basis of the size of their territory (Mackil, 2013: 298). Standard coinage was produced by multiple Boiotian mints suggesting formalized economic cooperation (Mackil, 2013:248-249).

The unity of the league against external threats did not entirely prevent violent disagreements between Boiotian cities (Mackil 2013:29). After the Greek defeat at Thermopylae, Thebes and most of Boeotia sided with the Persians during the Persian invasions of 480 and 479 BCE. After the subsequent Greek naval victory over the Persians, the Boiotian League was dissolved. While the League was able to reform and secure a major military victory over Athens (while allied with Sparta) in 446 BCE (Mackil, 2014:273), a later defeat by the Athenians resulted in the destruction of cities and crops. The league later opposed Sparta in the Corinthian War (395-387) and was again defeated and again dissolved. Aristotle noted that "the democracy [of Thebes] was destroyed as a result of bad government" (Mackil, 2013:34-35). As such, it may have been a combination of military defeat and the inability to maintain or reconstitute the institutional structure of the confederacy that brought about its end.

\section{Classical and Hellenistic Greece}

In Classical and Hellenistic Greece, koina (singular: koinon) were ancient Greek federal states that arose out of the cooperation of city-states (poleis) and villages. According to Mackil (2014:271): “The koinon was something radically different from the ethnos, a complex, regional state with a careful and deliberate distribution of power among several interdependent scales (polis, district, and koinon), rather than a group of communities with loose and informal structures for cooperation." Koinon were inherently cooperative and developed as a means for closely interacting city-states to formalize an institutional basis for collective action. Both access to and acquisition of resources beyond individual polis and ethnos and military security were major factors that led both urban and rural peoples to enter into a koinon (Mackil, 2014:280).

In Classical and Hellenistic times, the Achaean League was the most successful institution to have emerged in an attempt to unite the Greek city-states on the Peloponnese. The first Achaean league arose in the fifth century. The league was named after the region of Achaea in the northwestern Peloponnese, which formed its original core, with the city of Helike serving as capital. The destruction of the ancient capital by an earthquake and tsunami in $373 \mathrm{BCE}$ led to the dissolution of this initial league. It was reformed in $280 \mathrm{BCE}$ in opposition to Macedon and as an ally to Rome (Caspari, 1914).

As the League expanded, new members were promised internal autonomy and freedom from the confederacy's garrisons, in exchange for the mutual swearing of oaths that served as agreements about the terms of incorporation (Mackil, 2014:279). The Achaean League comprised both rural agriculturalists and urban commercial traders and the governing structure of the League evolved to meet the needs of an expansive populace (Caspari, 1914:212). This involved agreements to hold assemblies in various member cities on a rotating basis (Mackil, 2014:279). 
Councils of magistrates established institutions to facilitate access to the variable resources of the territory, including establishing frameworks for property rights, management of resources in times of scarcity, and facilitating economic interdependence of the poleis and their citizens (Mackil, 2014: 280). The koinon of Hellenistic Greece are one of the more centralized examples discussed herein, transforming into a structure more akin to a federal state than a confederation during its later history.

The Achaean League effectively organized for wars against other koinon such as the Aetolian League and the Macedonians. However, a failure in diplomatic relations with Rome eventually led to their defeat and collapse. Following the defeat of the League at the Battle of Corinth, the city was razed, and the League dissolved in $146 \mathrm{BCE}$, ushering in the Roman era.

\section{Korea}

The Three Kingdoms Period of Korean history speaks of confederated peoples known as Old Joseon (also Kochosŏn, Gojoseon) in the northern Korean peninsula ca. $300 \mathrm{CE}$, as chronicled in textual documents and known to some extent from archaeological data (Lee et al., 2005). In the southern Korean peninsula, Old Joseon's counterpart was Jin (also Chin) also being described as a loose confederacy (Gibson, 2011:222). “These confederacies ultimately broke apart into their constituent units (geosuguk), which then reformed into new confederacies: Puyŏ (also Buyeo), Koguryŏ (also Goguryeo), Ye, the Three Han (Samhan), and Gaya (or Kaya)" (Gibson, 2011:222).

Of these latter confederacies, we can take a closer look at Koguryŏ, first noted in Chinese history as a loose affiliation of five tribes (Parker, 1890:185) or a confederation of five clans (Sanguo $J i)$ living in the rugged terrain north of the Yalu river. Whichever is the case, these groups appear to have been multiethnic in nature and pressed by the expanding Chinese empire and possibly also the nomadic peoples on China's northern Frontier. The result was the development of a culture that included warriors on horseback that posed intermittent threats to China's northern frontier (Nelson, 1993: 208-209).

The purpose of the confederacy seems to have been to defend member territory from Chinese Imperial encroachment. Each clan within the confederacy constituted a basic military unit. The chief of each clan formed the governing body of the confederacy, with one chief elected from this body as "supreme commander" (Nelson, 1993:209). In the first century BCE this chieftainship became an inherited office, after which time the confederacy was transformed to a kingdom and from which the Koguryŏ, one of the Three Kingdoms, traces its origins (Joe, 1972:22).

On the tip of the southern peninsula, the Kaya (or Gaya) confederacy developed at the mouth of the Naktong River and region to the west. This was a confederacy of six polities collectively known as the Kaya (Nelson 199: 237). Similar to the situation in the north, the Kaya polities developed from the chiefly political structures of the twelve tribes of the ancient Byeonhan confederacy, which existed from around the beginning of the common era to approximately 400 CE. Of the Kaya polities, two of these (Ponkaya or "root" Kaya and Taekaya or "great" Kaya) were the strongest of the group. Military and political parity among the six prevented the development of a central state (Kim, 1982).

The basis of the Kaya economy was trade in iron, emphasizing mining, processing into tools and weapons, as well as ingots traded within the Korean peninsula, the Japanese highlands and with China (Nelson, 1993:237). While hill-top fortresses and evidence of a militaristic society are clear from burials (iron armor and weapons; mounted cavalry in wallpaintings) (Nelson, 1993:238-241), it is unclear if the primary objective of the Kaya confederacy was maintaining the stability needed to support their trade-based economy or resisting military incursions from the Silla and Baekje kingdoms that flanked their northern, eastern, and western borders. Some indication of the latter comes from the fact that the Kaya confederacy was later conquered by Silla, one of the Three Kingdoms of Korea, an annexation that was complete by 562 CE (Nelson, 1993:247).

In these cases, there is a deep history of confederated polities in the region. Ultimately, the military and economic objectives of Korean confederacies were unable to withstand the centrifugal forces of state formation either within their own region or the territorial ambitions of adjacent, more centralized polities.

\section{Postclassic Maya}

Located on the Yucatan peninsula of Mexico, the polity centered upon the Postclassic Maya city of Mayapan has been described as both a state and a confederacy (Masson, 2021). It was founded between 1,150 (Masson, 2021) and 1300 CE (Roys, 1957), was transformed during the period of Spanish conquest, and persisted until ca. $1600 \mathrm{CE}$. The population of Mayapan itself has been estimated at some 16,000-17,000 (Masson, 2012). Population estimates from the Spanish era record towns and provinces with populations ranging from the thousands to tens of thousands (Roys, 1957).

The Mayapan confederacy emerged following the collapse of the polity centered upon Chichén Itzá. Its purpose appears to have been to provide a political and institutional framework for the expansive economic network that straddled the northern Yucatan. The 900-1200 CE period is marked by the abandonment of southern lowland city-states and a northward shift in population and activity. While famously painted as a "collapse" (Demarest et al., 2004; Turner and Sabloff, 2012), more recent scholarship inverts earlier perspectives and asserts that "Postclassic Maya society represents a resilient reconstitution rather than a collapsed remnant of a Classic period apocalypse" (Masson, 2021:280).

The Mayapan confederacy consisted of 10 territorially contiguous cuchcabal (jurisdiction, translated to provinces by the Spanish) (Roys, 1957:3). Each province was ruled from a prominent town. The city of Mayapan functioned as a confederacy capital. Individual provinces had various systems of governance, some rather centralized under a single ruler or ruling class and some consisting of a loosely allied groups of 
towns. All provinces had multiple towns, each headed by a local head (batab) who was supported by the town and who performed executive, judicial, and military functions (Roys, 1957:6). Lands were held in common by the town, but improvements such as fruit trees and cultivated crops were private property (Roys, 1957:8).

Provincial leaders were members of leading or elite lineages and sat on an assembly or council of lords. The council served as an institution of joint government (multepal) and permitted multiple elites to participate in governance, and although influence was not distributed evenly among members, it provided a place to "negotiate, advocate, and resolve conflict" (Masson, 2021:292).

Each of the lords of Mayapan built their own administrative groups in the site's monumental core. Despite not being as architecturally impressive as Classic period monumental architecture, these compounds were lavish, with colonnaded halls, temples, oratories, shrines and other "trappings of high culture" (Masson, 2021:286). Contact-period accounts further suggest that these lords were able to mobilize and tax thousands of laborers and subjects. Elite compounds in Mayapan were supported by produce and resources from their home provinces (Sharer and Traxler, 2006:602). Variable wealth divisions also existed among commoners, with urban commoners being somewhat better off than the rural poor (Masson, 2021:285). Civil and religious offices were distributed amongst these elite factions (Sharer and Traxler, 2006:601).

In its early years, Mayapan became a major commercial center, controlling production and trade in salt, pigments, cotton textiles, honey, pottery, copper, obsidian, and slaves, among other commodities (Sharer and Traxler, 2006:599). Evidence for links to central Mexico and down the Caribbean coast point to an expansive cultural and economic network. Early Spanish accounts of the region describe thriving commercial towns, bustling markets, rich merchants, and canoes piled high with merchandise (Kepecs, 1999:7).

Although Mayapan's centralized governing structure certainly meets our definition of confederacy-meeting strategic aims while maintaining local autonomy, there is the question of whether or not Mayapan's confederacy constituted "good government?" Reports indicate that certain Maya lords wielded considerable power, with the capacity to mobilize and tax thousands of laborers and subjects, and many of them lived affluently.

There is evidence for a decline in societal well-being in the 14th century at the Mayapan capital, including evidence for famine, interpersonal violence, and political unrest, as well as evidence for out-migration. In the mid-fifteenth century, it appears that climatic challenges exacerbated factionalism within the confederacy, "causing unrest and triggering a concerted military effort orchestrated from within the governing council by the Xiu faction, mounted against the influential Cocom faction. Following the massacre of the Cocom and the abandonment of the city, regional unity ended" (Masson, 2021:284). Governance returned to the local level.
Environmental hardship aggravated political divisions caused by Mayapan's fall and early colonial accounts indicate that there was much inter-provincial warfare just prior to Spanish arrival (Landa, 1941:41). In this way, although the confederacy seems to have been forged in order to promote commerce, the suppression of conflict amongst members was also a feature that collapsed with the collapse of the confederacy governance.

\section{DISCUSSION}

These case studies uphold the thesis that confederacies functioned to achieve strategic collective action at a distance while preserving local autonomy. In terms of aims and objectives, there appear to be two primary reasons confederacies formed: one military and one economic. Assessing whether or not confederacies were "good government" in Blanton (2020), Blanton (2021) terms is a slightly more complicated question because governance was inherently local. The business of the confederacy was to achieve strategic objectives, not to govern local populations. When confederacies did govern it was weakly and their will could be subverted at the local level or result in transformation into another form of political organization.

In the cases discussed herein, the most common strategic aim of confederation was organization for joint military action. In some cases, this was due to external forcing in the form of aggressive or expansive neighbors (e.g., Wendat, northern Korea, Germania, Near East, Muscogee); in others, forming a joint military unit also served to reduce conflict between members of the confederacy (e.g., Haudenosaunee, Old Swiss). However, once a confederation was effectively militarized, they were capable of engaging in defensive or offensive action (e.g., Ireland). The second most common strategic objective was economic in nature. In some cases, confederacies formed in order to facilitate trade and exchange by lowering transaction costs among members and providing an institutional framework that supported trade, exchange, and markets among its constituent parts (e.g., Mayapan). In multiple cases, both military and economic objectives were achieved, either intentionally or as a consequence of one or the other (e.g., Old Swiss, Greece). It is notable that two of the most economicallymotivated confederations: The Old Swiss Confederacy and the confederacy centered at Mayapan also included the most intragroup conflict in the cases above. These two cases were the most durable confederacies discussed herein, each persisting for $\sim 500$ and $\sim 400$ years, respectively. The shortest-lived confederacies were those of Boeotia and the Shahsevan, each persisting for a century or so, with the set having an average of $\sim 250$ years. This may not mean that confederation for economic motivations is a recipe for political longevity so much as the fact that the others formed in places and times that were more prone to conflict and the political instability it engenders. Nevertheless, an important direction of future research should involve detailed attention to how military, economic, and political objectives were financed by members of confederacies. Mackil's (2013) close analysis of the fiscal regimes of Greek confederations could serve as a model. A concurrent question relates to the impact of the environment on 
the development of confederacies and how they might have been affected by ecological (as well as historical) change.

Did confederacies constitute "good government" in Blanton (2020, 2021) terms? Based on variability in the cases described above, I believe the answer is no. Although, when functioning correctly, the strategic military or economic goals of a confederacy ostensibly provided benefits to the populace. Good governance involves mutual moral commitments between leaders and citizens (Blanton et al., 2020). Physical and economic security are thus paramount among the institutional relationships between the leaders of a confederacy and their populaces.

In some cases, such as the Northern Iroquoian and Muscogee cases, the distribution of authority amongst leaders and representatives of nations, towns, and kin groups meant that there was a better chance that "the will of the people" was represented at the confederacy level. It may be significant that in these cases, disagreements between members in one case lead to the dissolution of the confederacy and in the other civil war. In neither case, was transformation into a more centralized or coercive political structure a culturally-permissible possibility. In other cases, (e.g., Ireland, Germania, Mayapan) hereditary leadership and succession dampened or prevented the will of the people to be exercised in political decision-making. As such, we cannot say that premodern confederacies were uniformly more "democratic" than early states.

A point that contrasts sharply with the notion of a confederacy as a societal "type" is that in a number of cases, (e.g., Mayapan, Germania, Old Swiss, Greece) the constituent units within a confederacy were governed in diverse ways-from more to less centralized with varying degrees of entrenched hierarchy, mechanisms for the extraction of revenue, and collective benefits (or not) for the populace. Collective action and social inequality are perfectly capable of co-existing in all kinds of human social configurations ranging from hunter-gatherers (Wengrow and Graeber, 2015) to pre-modern states (Blanton and Fargher, 2008). The flexible and durable properties of confederacies show them to be another such example of political innovation, but neither confederacies nor their constituent parts correspond to a neatly constrained societal type.

In some cases, i.e., the Lords of Mayapan and Alamanni kings, leaders did not necessarily act in the interests of their subjects. In some cases, desire to extract taxation and tribute to support ambitions beyond those of the populace (e.g., elite consumption, predatory expansion) was, in the Medieval Irish and Iron Age Korean cases, the thing that transformed them into kingdoms and feudal states. In the absence of centralization around a single authority, the confederacy-as-institution grew powerful enough to impose it is will on member nations or provinces, the confederacy was transformed into something more akin to a federal state, as was the case among the Hellenistic Greek Koinon and the Swiss.
Blanton et al. (2020:2) identify scholars that suggest that "weak" premodern states were as such because they failed to extract revenue in the form of taxation due to the friction of distance or a lack of information (about potential sources of revenue) (Mayshar et al., 2017; Stasavage, 2020). In response to this critique about the effectiveness of confederacies as political structures, I return to the central thesis of this paper: That the purpose of a confederacy was not to govern, per se, but rather to achieve collective objectives while preserving local autonomy. The centralization of revenue-generation in order to support a structure of social control was exactly the opposite of what confederation was designed to achieve. The price of that autonomy was a less stable political apparatus than can be accomplished through the centralizing tendencies of the state. In this way, confederation is an ongoing process of negotiation as opposed to a single set of roles or relations aimed at consolidating power and revenue.

While the concept of a confederacy is often equated with principles of equality and democratic relations among members (Engels, 1884; Trigger, 1976), the cases discussed herein have shown that the degree of "good government" that exists both at and below the level of the confederacy as an institution can vary significantly. Future directions in investigating and theorizing confederacies could productively interrogate that variability with respect to strategic goals and component parts. For example, what is the interplay between local or sub-regional economic structures and the financing of collective objectives (military or otherwise) in confederacies with variable political components? Is some degree of centralization, i.e., the role of Thebes in the Boiotian League or Mayapan in the Yucatan, a stabilizing or destabilizing force? Certainly, the examples and conclusions reached here suggest that pre-modern confederacies are worth studying with the same degree of rigor that has been applied to their counterparts among pre-modern and early states.

\section{AUTHOR CONTRIBUTIONS}

The author confirms being the sole contributor of this work and has approved it for publication.

\section{ACKNOWLEDGMENTS}

I thank the topic editors, Gary Feinman, Richard Blanton, Stephen Kowalewski, and Lane Fargher for their invitation to contribute to this Research Topic. Thanks to the three reviewers provided constructive feedback on the original manuscript. Thanks also to Stephen Kowalewski and Stefan Brannan for their helpful conversations around the subject matter. 


\section{REFERENCES}

A. A. Demarest, P. M. Rice, and D. S. Rice (Editors) (2004). The Terminal Classic in the Maya Lowlands: Collapse, Transition, and Transformation (Boulder: University Press of Colorado).

Birch, J., Manning, S. W., Sanft, S., and Conger, M. A. (2021). Refined Radiocarbon Chronologies for Northern Iroquoian Site Sequences: Implications for Coalescence, Conflict, and the Reception of European Goods. Am. Antiq. 86 (1), 61-89. doi:10.1017/aaq.2020.73

Birch, J. (2020). "Social Institutions and the Differential Development of Northern Iroquoian Confederacies," in The Evolution of Social Institutions: Interdisciplinary Perspectives. Editors D. M. Bondarenko, S. A. Kowalewski, and D. B. Small (Switzerland: Springer Nature), 419-435. doi:10.1007/978-3030-51437-2_19

Blanton, R. E., and Fargher, L. (2008). Collective Action in the Formation of Premodern States. New York: Springer.

Blanton, R. E., Fargher, L. F., Feinman, G. M., and Kowalewski, S. A. (2021). The Fiscal Economy of Good Government. Curr. Anthropol. 62 (1), 77-100. doi:10. $1086 / 713286$

Blanton, R. E., Feinman, G. M., Kowalewski, S. A., and Fargher, L. F. (2020). Moral Collapse and State Failure: A View from the Past. Front. Polit. Sci. 2, 568704. doi:10.3389/fpos.2020.568704

Brandão, J. A. (1997). Your Fyre Shall Burn No More: Iroquois Policy toward New France and its Native Allies to 1701. Lincoln: University of Nebraska Press.

Buck, R. J. (1979). A History of Boeotia. Edmonton: University of Alberta Press.

Butler, R. (2021). Tribal Histories Series - Muscogee Nation, 15. Presentation to the Oklahoma History Network, 2021. Sept.

Caspari, M. O. B. (1914). The Parliament of the Achaean League. Engl. Hist. Rev. 29 (114), 209-220. doi:10.1093/ehr/xxix.cxiv.209

Chaudhuri, J., and Chaudhuri, J. (2001). A Sacred Path: The Way of the Muscogee Creeks. Los Angeles: UCLA American Indian Studies Center.

Cobb, C. R. (2019). The Archaeology of Southeastern Native American Landscapes of the Colonial Era. Gainesville: University Press of Florida.

Dean, S. E. (2012). A Blow to Swiss Ambitions. Medieval Warfare 2 (5), 26-32.

Engels, F. (1884). The Origin of the Family, Private Property and the State. Chicago: Charles H. Kerr and Company.

Fenton, W. N. (1998). The Great Law and the Longhouse: A Political History of the Iroquois Confederacy. Tulsa, OK: University of Oklahoma Press.

Finkelstein, I., Ussishkin, D., and Halpern, B. (2000). Megiddo III: The 1992-1996 Seasons. Tel Aviv: The Institute of Archaeology of Tel Aviv University.

Gibson, D. B. (2011). Chiefdom Confederacies and State Origins. Soc. Evol. Hist. 10 (1), 215-233.

Gibson, D. B. (1995). "Chiefdoms, Confederacies, and Statehood in Early Ireland," in Celtic Chiefdom, Celtic State. Editors B. Arnold and D. B. Gibson (Cambridge: Cambridge University Press), 116-128.

Gibson, D. B. (2012). From Chiefdom to State in Early Ireland. Cambridge: Cambridge University Press.

Gottwald, N. K. (1979). The Tribes of Yahweh: A Sociology of the Religion of Liberated Israel, 1250-1050 B.C.E.. NY: MaryknollOrbis.

Hannah, E., and McLaughlin, R. (2019). Long-term Archaeological Perspectives on New Genomic and Environmental Evidence from Early Medieval Ireland. J. Archaeological Sci. 106, 23-28. doi:10.1016/j.jas.2019.04.001

Heather, P. (2010). Empires and Barbarians: The Fall of Rome and the Birth of Europe. Oxford: Oxford University Press.

Hermann, C. F. (1836). Manual of the Political Antiquities of Greece, Historically Considered. Oxford: D.A. Talboys.

Hunt, T. (2010). Introduction to the Origin Of the Family, Private Property And the State. London: Penguin.

Joe, W. J. (1972). Traditional Korea: A Cultural History. Seoul: Chung'ang University Press.

Jones, E. E. (2008). Iroquois Population History and Settlement Ecology, AD 1500-1700. [dissertation]. College Station (PA): Pennsylvania State University.

Kepecs, S. (1999). The Political Economy of Chikinchel, Yucatan, Mexico: A Diachronic Analysis from the Prehispanic Era through the Age of Spanish Administration. [dissertation]. [Madison]. University of Wisconsin-Madison.
Kim, J-H. (1982). The Development of Ancient State "Kaya. Hanguk Kogo Hakbo 5, 1-16.

Knight, V. J. (1994). "The Formation of the Creeks," in The Forgotten Centuries: Indians and Europeans in the American South. Editors C. Hudson and C. C. Tesser (Athens: University of Georgia Press), 1521373-1704392.

Kowalewski, S. A., and Thompson, V. D. (2020). Where Is the Southeastern Native American Economy. Southeast. Archaeology 39 (4), 281-308. doi:10.1080/ 0734578x.2020.1816599

Landa, D. de. (1941) Relaciones de las Cosas de Yucatan, translated by A. Tozzer. Papers of the Peabody Museum of Archaeology and Ethnology 18. Cambridge: Harvard University Press.

Lapham, H. (2005). Hunting for Hides: Deerskin, Status, and Cultural Change in the Protohistoric Appalachians. Tuscaloosa: University of Alabama Press.

Lee, H., Park, S., and Yoon, N. (2005). "New History of Korea," in Korean Studies Series No. 30 (Seoul: Jimoondang).

Levi, M. (1988). Of Rule and Revenue. Berkeley: University of California Press. Mac Sweeney, N. (2010). Hittites and Arzawans: a View from Western Anatolia. Anatol. Stud. 60, 7-24. doi:10.1017/s0066154600000995

Mackil, E. (2013). Creating a Common Polity: Religion, Economy, and Politics in the Making of the Greek Koinon. Berkley: University of California Press.

Mackil, E. (2014). "Ethnos and Koinon," in A Companion to Ethnicity in the Ancient Mediterranean. Editor J. McInerney (Malden MA: John Wiley \& Sons), 270-284. doi:10.1002/9781118834312.ch18

Martin, J. D. (1989). "Israel as a Tribal Society," in The World of Ancient Israel: Sociological, Anthropological, and Political Perspectives. Editor R. E. Clements (Cambridge: Cambridge University Press), 95-118.

Masson, M. A. (2012). Maya Collapse Cycles. Proc. Natl. Acad. Sci. 109 (45), 18237-18238. doi:10.1073/pnas.1213638109

Masson, M. (2021). "Resiliency and Cultural Reconstitution of the Postclassic Mayapan Confederacy and its Aftermath," in Mesoamerican Archaeology: Theory and Practice. Editors J. A. Hendon, L. Overholtzer, and R. A. Joyce (Malden, MA: John Wiley \& Sons), 278-314.

Mayshar, J., Moav, O., and Neeman, Z. (2017). Geography, Transparency, and Institutions. Am. Polit. Sci. Rev. 111 (3), 622-636. doi:10.1017/ s0003055417000132

Merrills, A., and Miles, R. (2010). The Vandals. Oxford: Willey-Blackwell.

Morgan, L. H. (1877). Ancient Society, or Researches in the Lines of Human Progress from Savagery through Barbarism to Civilization. Chicago: Charles H. Kerr \& Co.

Morgan, L. H. (1851). League of the HO-DE'-NO-SAU-NEE or Iroquois. Rochester: Sage \& Brother.

Muller, J. (1997). Mississippian Political Economy. New York: Springer.

Nelson, S. M. (1993). The Archaeology of Korea. Cambridge: Cambridge University Press.

Ostrom, E. (1990). Governing the Commons: The Evolution of Institutions for Collective Action. Cambridge: Cambridge University Press.

Parker, E. H. (1890). On Race Struggles in Korea. Trans. Asiatic Soc. Jpn. 23, 137-228.

Parmenter, J. (2018). The Edge of the Woods: Iroquoia, 1534-1701. Ann Arbor: Michigan State University Press.

Pavlish, L. A., Michelaki, K., Moreau, J. F., Farquhar, R. M., Fox, W., Anselmi, L. M., et al. (2018). Tracing the Distribution of Late 16th and Early 17th Century European Copper Artefacts in Southern Québec and Ontario, Canada. Archaeometry 60 (3), 517-534. doi:10.1111/arcm.12323

R. Ethridge and C. Hudson (Editors) (2002). The Transformation of the Southeastern Indians, 1540-1760 (Jackson: University Press of Mississippi).

Roys, R. L. (1957). The Political Geography of the Yucatan Maya, 613. Washington D.C.: Carneigie Institution Publication.

Schelbert, L. (2014). Historical Dictionary of Switzerland. Second ed. Lanham, MD: Rowman \& Littlefield

S. D. Gartland (Editor) (2016). Boiotia in the Fourth Century B.C (Philadelphia: University of Pennsylvania Press).

Sharer, R., and Traxler, L. (2006). The Ancient Maya. 6th ed. Stanford: Stanford University Press.

Smith, D. E. (2003). The Tent and the Temple: The Tension between Confederation and Kingship in Ancient Israel. Hist. Polit. Thought 24 (4), $561-576$. 
Stasavage, D. (2020). The Decline and Rise of Democracy. Princeton: Princeton University Press.

Swanton, J. R. (1922). Early History of the Creek Indians and Their Neighbors. Washington: US Government Printing Office.

Tapper, R. (1990). "Anthropologists, Historians, and Tribespeople on Tribe and State Formation in the Middle East," in Tribes and State Formation in the Middle East. Editors P. S. Khoury and J. Kostiner (Berkeley: University of California Press), 48-73.

Tapper, R. (1997). Frontier Nomads of Iran. Cambridge: Cambridge University Press.

Thompson, V. D., Holland-Lulewicz, J., Butler, R., Hunt, T., Wendt, J., Wettstaed, J., et al. (2022) The Early Materialization of Democratic Institutions Among the Ancestral Muskogean of the American Southeast. Under review with American Antiquity.

Tooker, E. (1964). An Ethnography of the Huron Indians, 1615-1649, 190. BulletinWashington: Smithsonian Institution, Bureau of American EthnologyU.S. Government Printing Office.

Trigger, B. G. (1976). The Children of Aataentsic: A History of the Huron People to 1660. Montreal and Kingston: McGill-Queens University Press.

Turner, B. L., II, and Sabloff, J. A. (2012). Classic Period Collapse of the Central Maya Lowlands: Insights about Human-Environment Relationships for Sustainability. Proc. Natl. Acad. Sci. 109 (35), 13908-13914. doi:10.1073/ pnas. 1210106109

van der Steen, E. J. (2005). The Sanctuaries of Early Bronze IB Megiddo: Evidence of a Tribal Polity. Am. J. Archaeology 109 (1), 1-20. doi:10.3764/aja.109.1.1

Warrick, G. A. (2008). A Population History of the Huron-Petun, AD 500-1650. Cambridge: Cambridge University Press.

Weir, H. T., III (2016). A Paradise of Blood: The Creek War of 1813-14. Yardley, PA: Westholme Publishing.

Wengrow, D., and Graeber, D. (2015). Farewell to the 'childhood of Man': Ritual, Seasonality, and the Origins of Inequality. J. R. Anthropol. Inst. 21, 597-619. doi:10.1111/1467-9655.12247

Wickham, C. (2016). Medieval Europe. New Haven: Yale University Press.
Williamson, R. F., and Steiss, D. A. (2003). "A History of Iroquoian Burial Practice," in Bones of the Ancestors: The Archaeology and Osteobiography of the Moatfield Ossuary. Editors R. F. Williamson and S. Pfeiffer (Gatineau, QC: Canadian Museum of Civilization), 89-132.

Wonderley, A., and Sempowski, M. (2019). Origins of the Iroquois League. Syracuse: Syracuse University Press.

Würgler, A. (2008). "'The League of the Discordant Members' or How the Old Swiss Confederation Operated and How it Managed to Survive for So Long," in The Republican Alternative, The Netherlands and Switzerland Compared. Editors A. Holenstein, T. Maissen, and M. Prak (Amsterdam: Amsterdam University Press), 29-50.

Young, A. T. (2015). From Caesar to Tacitus: Changes in Early Germanic Governance Circa 50 BC-50 AD. Public Choice 164, 357-378. doi:10.1007/ s11127-015-0282-7

Zank, M. (2008). Holy City: Jerusalem in Time, Space and Imagination. Available at: http://www.bu.edu/mzank/Jerusalem/p/period0.htm. Accessed 10//28/2021.

Conflict of Interest: The author declares that the research was conducted in the absence of any commercial or financial relationships that could be construed as a potential conflict of interest.

Publisher's Note: All claims expressed in this article are solely those of the authors and do not necessarily represent those of their affiliated organizations, or those of the publisher, the editors and the reviewers. Any product that may be evaluated in this article, or claim that may be made by its manufacturer, is not guaranteed or endorsed by the publisher.

Copyright $\odot 2022$ Birch. This is an open-access article distributed under the terms of the Creative Commons Attribution License (CC BY). The use, distribution or reproduction in other forums is permitted, provided the original author(s) and the copyright owner(s) are credited and that the original publication in this journal is cited, in accordance with accepted academic practice. No use, distribution or reproduction is permitted which does not comply with these terms. 